\title{
Optimization of Photosynthetic Productivity in Contrasting Environments by Regulons Controlling Plant Form and Function
}

\author{
Barbara Demmig-Adams ${ }^{1, *}$, Jared J. Stewart ${ }^{1}{ }^{(0)}$, Christopher R. Baker ${ }^{2}$ \\ and William W. Adams III 1 (i) \\ 1 Department of Ecology \& Evolutionary Biology, University of Colorado, Boulder, CO 80309-0334, USA; \\ jared.stewart@colorado.edu (J.J.S.),william.adams@colorado.edu (W.W.A.) \\ 2 Department of Plant \& Microbial Biology, University of California, Berkeley, CA 94720-3102, USA; \\ cbaker@berkeley.edu \\ * Correspondence: barbara-demmig-adams@colorado.edu; Tel.: +1-303-492-5541
}

Received: 30 January 2018; Accepted: 13 March 2018; Published: 15 March 2018

\begin{abstract}
We review the role of a family of transcription factors and their regulons in maintaining high photosynthetic performance across a range of challenging environments with a focus on extreme temperatures and water availability. Specifically, these transcription factors include CBFs (C-repeat binding factors) and DREBs (dehydration-responsive element-binding), with CBF/DREB1 primarily orchestrating cold adaptation and other DREBs serving in heat, drought, and salinity adaptation. The central role of these modulators in plant performance under challenging environments is based on (i) interweaving of these regulators with other key signaling networks (plant hormones and redox signals) as well as (ii) their function in integrating responses across the whole plant, from light-harvesting and sugar-production in the leaf to foliar sugar export and water import and on to the plant's sugar-consuming sinks (growth, storage, and reproduction). The example of Arabidopsis thaliana ecotypes from geographic origins with contrasting climates is used to describe the links between natural genetic variation in CBF transcription factors and the differential acclimation of plant anatomical and functional features needed to support superior photosynthetic performance in contrasting environments. Emphasis is placed on considering different temperature environments (hot versus cold) and light environments (limiting versus high light), on trade-offs between adaptations to contrasting environments, and on plant lines minimizing such trade-offs.
\end{abstract}

Keywords: acclimation; adaptation; Arabidopsis thaliana; C-repeat binding factor (CBF); dehydration-responsive element-binding (DREB); photosynthesis; source-sink; transcription factors

\section{Introduction}

Photosynthesis converts sunlight into food, plant-derived materials, and carbon-based fuels. Continuing human population growth increases the demand for these necessities, while extreme climate events threaten crop productivity. It is thus pivotal to maintain or increase plant productivity, and specific targets to achieve this goal include improvement of rates and efficiency of photosynthesis [1,2]. Plants fine-tune their investment in photosynthetic capacity in response to environmental conditions; this review focuses on temperature, water availability, and sunlight. Improving crop yields as climate changes will require a deepened mechanistic understanding of plant features supporting high plant productivity under challenging environmental conditions. Many studies on temperature effects have focused on the extremes of lethal freezing or heat (e.g., [3,4]) and on damage from membrane disruption and leakage (e.g., $[5,6])$. However, the non-lethal temperatures between these extremes profoundly impact photosynthetic performance and plant productivity. Here, we review plant features that 
support high photosynthetic productivity over a range of temperature and light environments. We end with a synopsis of recently identified trade-offs in the ability of locally adapted populations of the winter annual model species Arabidopsis thaliana to maintain photosynthetic productivity in contrasting environments. This concluding section focuses on selected transcription factors, signaling networks, and the foliar vasculature's role in exchanging sugar and water between the photosynthesizing leaf and the rest of the plant. We hope that this insight will be helpful in efforts to improve crops for enhanced productivity under a changing and increasingly unpredictable climate.

High plant productivity in any given environment depends on high activities of three key functions (Figure 1): (i) photosynthetic capacity of source leaves; (ii) the capacities of the leaf's sugar-exporting and water-importing vascular pipelines; and (iii) activity of plant sinks (sum of growth, reproduction, and storage). Source leaf photosynthesis is the plant's engine (see [7]). Sugar demand from plant sinks influences the expression of photosynthetic genes [8]; sufficient foliar sugar-export capacity is needed to prevent protracted foliar sugar accumulation and photosynthetic gene repression $[9,10]$. Moreover, adequate foliar water-import capacity must replace water lost during carbon uptake to ensure continued stomatal opening and access to atmospheric carbon dioxide [11,12].

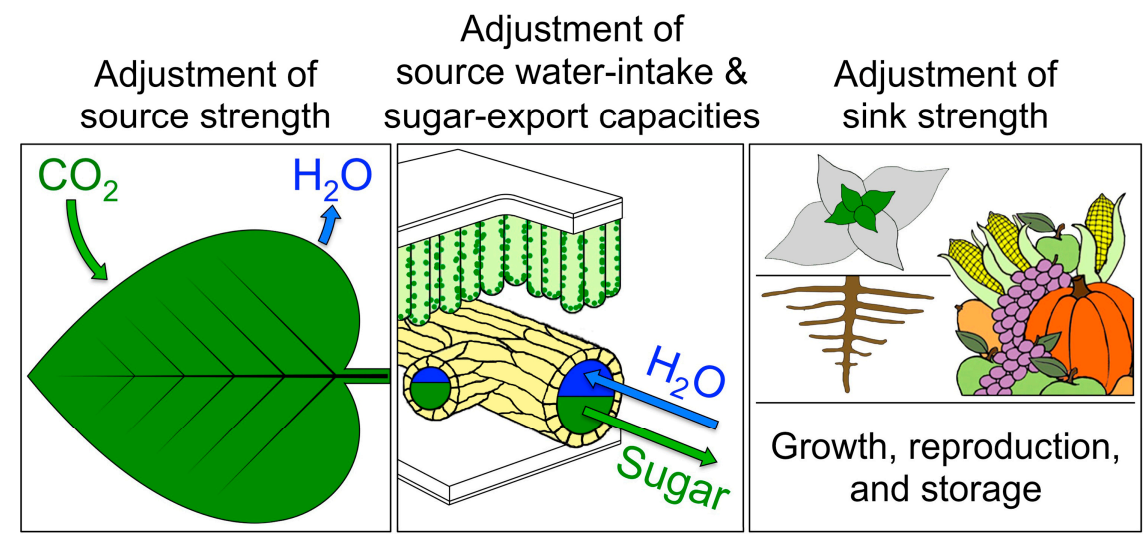

Figure 1. Schematic depiction of the three proposed adjustments necessary for plant productivity in a given environment: (i) photosynthetic capacity (light- and $\mathrm{CO}_{2}$-saturated intrinsic capacity of photosynthesis determined by the level of photosynthetic proteins) to provide sugars (the plant's source strength) fueling crop yield; (ii) high flux capacities for distributing water throughout the leaf as well as loading and exporting sugars from the leaf (foliar water-intake \& sugar-export capacities; see Section 4.5 below); and (iii) sink activity (growth, reproduction, and storage; sink strength). Modified from Demmig-Adams et al. [7] and Adams et al. [10]. The left panel illustrates $\mathrm{CO}_{2}$ uptake and water loss through leaf stomates, which requires sufficient water delivery to the leaf. The middle panel shows a leaf vein that contains conduits for water import (blue) into and conduits for sugar export (green) out of the leaf. The right panel shows examples of sugar-consuming and -storing sink tissues that constitute the plant's demand for photosynthate.

The intrinsic photosynthetic capacity is adjusted in response to the combined sugar demand from all sink tissues, with a high photosynthetic capacity when total sink activity is high $[7,8]$. Vegetative growth of shoots and/or roots is one possible sink and trigger for photosynthetic upregulation, while storage of photosynthate and reproduction are alternative key sinks that can also support high photosynthetic capacity. Therefore, plant productivity is the sum-total of vegetative growth, energy storage, and flower and seed/fruit production. In fact, strong increases in the yield of grain/fruit crops were achieved in numerous instances by the generation of dwarf varieties or pruning practices that led to an increased allocation of photosynthate to grain/fruit yield relative to vegetative growth (reviewed, e.g., in [7]).

The above functions (photosynthetic capacity, sugar- and water-transport capacity, and sink strength) are adjusted in response to the environment by orchestrated changes at the transcriptomic, 
metabolic, and phenotypic levels. The present review provides an overview of changes at these different levels, including selected transcription factors that co-optimize plant productivity and tolerance to cold, heat, and drought (Section 2), selected metabolic change (example of redox regulation; Section 3), and a case study of associated changes in plant form and function that support superior photosynthetic productivity under extreme temperatures (Section 4). Section 4 also illustrates genetic differences between locally adapted plant populations in the degree of these adjustments.

This insight underscores the need for a whole-plant perspective and integration of genomic and phenotypic information to develop plant genotypes with superior productivity. Progress in "profiling crop germplasm [that] has benefited from rapid advances in DNA sequencing" now needs to be matched with "similar advances [in] the throughput of plant phenotyping" [13]. We suggest that proxies for the leaf features reviewed here, including those responsible for foliar water import and sugar export, merit attention in the development of corresponding markers suitable for high-throughput phenotyping.

\section{Transcription Factors Co-Optimize Productivity and Stress Tolerance}

\subsection{CBFs/DREBs and Abiotic Stress Tolerance}

The present review focuses on a set of selected transcription factors with roles in maintaining high photosynthetic performance in extreme environments, i.e., the C-repeat binding factor (CBF)/ dehydration-responsive element-binding (DREB) family (for multiple prior reviews on this topic, see below). The centrality of these gene regulators for maintaining plant performance under challenging environments is based on their integrative coordination of multiple aspects of plant form and function as well as their interaction with central signal-transduction networks that link environmental cues to the transcriptome. These transcription factors coordinate multiple morphological, physiological, and biochemical adjustments across the plant (e.g., [14])—from light collection and sugar production in source leaves to the activity of sugar-consuming sinks (growth, storage, and reproduction) [15-17]. In addition, these transcription factors show cross-talk with key signaling networks that sense environmental cues [18], which makes these transcription factors subject to modulation by the environment.

CBFs/DREBs regulate the expression of genes responding to both low and high temperatures in A. thaliana [3,19] and other species (e.g., [20]; for reviews, see [18,21-24]). One branch of this transcription factor family serves primarily in orchestrating cold adaptation and the other primarily in orchestrating heat, drought, and salinity adaptation. Specifically, CBF1, 2, and 3-also known as DREB1B, C, and A, respectively-are prominent regulators of plant growth and development under cold temperature [25], while DREB2 transcription factors regulate the response to heat and drought $[19,26]$, and CBF4/DREB1D and DREB3 are implicated in ABA-dependent drought response (e.g., $[27,28])$. Despite these specialized roles, CBF/DREB1-type and DREB2-type transcription factors have additional overlapping functions in temperature adaptation [24].

The CBF transcription factors, furthermore, act on other transcriptional modulators, such as the regulator ICARUS1 of growth under high temperature in A. thaliana [29], and interact with plant hormones in coordinating growth under temperature extremes [30]. Moreover, Kurbidaeva et al. [31] demonstrated a role for natural genetic diversity in the INDUCER OF CBF EXPRESSION 2 gene in freezing tolerance among sixty $A$. thaliana ecotypes. While the evidence linking CBFs and freezing tolerance in A. thaliana is substantial [32-36], CBFs' role in orchestrating above-freezing, cool-temperature response may be even more important [37-41]. Specifically, the CBF regulon has been implicated in plant cool-temperature response involving thicker leaves with more chlorophyll and higher rates of photosynthesis per leaf area in $A$. thaliana, and constitutive overexpression of CBF transcription factors yielded the same phenotype in plants grown under moderate temperatures $[14,42,43]$. 


\subsection{Stress-Inducible Promoters: On-off Switches Minimize Yield Penalties}

A comprehensive review by Agrawal et al. [24] on the CBF/DREB system lists studies on transgenic expression of $C B F$ or other $D R E B$ genes in crops that produced gains in stress tolerance at the expense of growth retardation and yield penalties under optimal environmental conditions. Next, the latter review examined additional studies that used different promoters and achieved enhanced stress tolerance free of penalties under optimal conditions [26,28,44-46]. Agarwal et al. [24] concluded that "it is possible to decrease or eliminate negative influences of CBF/DREB-encoding transgenes on plant growth and yield by modulation of their levels of expression, through the use of stress-inducible promoters." In other words, stress-inducible promoters assist in combining high plant productivity under favorable conditions with high stress tolerance.

Switching the CBF/DREB regulons on or off via stress-inducible promoters involves cross-talk among plant hormones, cellular redox balance (the balance between stress-induced generation of reactive oxygen species [ROS], and the plant's production of antioxidants), and other messengers ([17,24]; see Figure 2). Reactive oxygen species, antioxidants, phytohormones, and sugars interact in the transduction of environmental cues into modulation of stress tolerance, programmed cell death, growth, and development $[47,48]$. Trends are complex due to local gradients in ROS and antioxidants, multiple types of ROS and antioxidant systems with different, sometimes antagonistic, effects, and the impacts of both environmental stimuli and genetic factors [47-49]. Redox signals modulate plant hormone synthesis, sequestration, and signal transduction. Phytohormones subject to redox modulation include abscisic acid, auxins, brassinosteroids, cytokinins, gibberellins, ethylene, salicylic acid, and jasmonic acid [16,47-51].

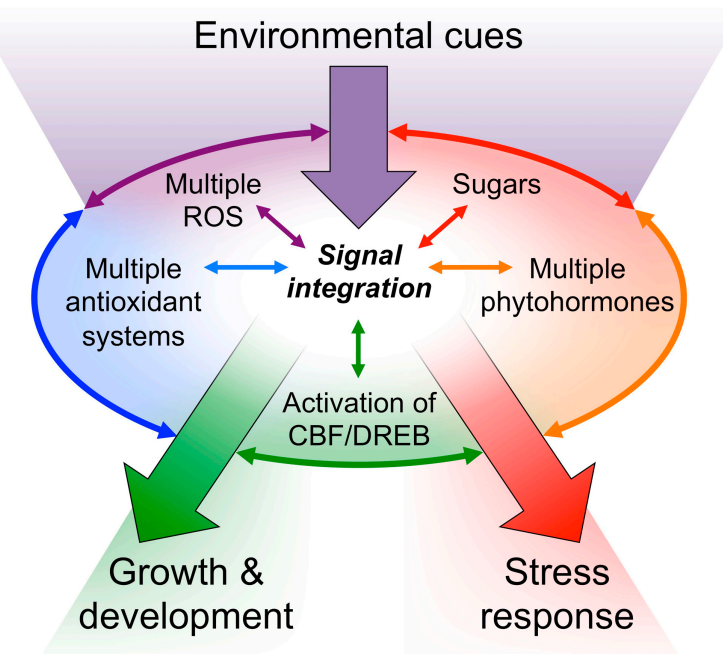

Figure 2. Schematic depiction of prominent signaling pathways involved in translating environmental cues (e.g., light and temperature) into phenotypic responses.

Reactive oxygen species have a dual role in cell expansion and growth. Under environmental stress, ROS can either stimulate or inhibit leaf and root cell expansion, depending on the specific ROS involved, their location, and other conditions [52,53]. More studies are needed to further elucidate interactions among transcription factors, oxidants/antioxidants, phytohormones, and sugar signals in the modulation of plant growth, photosynthetic performance under challenging environmental conditions, and the foliar vasculature responsible for water and sugar transport.

\subsection{To Grow or Not to Grow When the Going Gets Tough}

As mentioned in Section 2.2, stress-inducible promoters can minimize growth penalties under optimal conditions. In addition, growth cessation is not the only possible response to stressful conditions. 
In fact, either slowed growth or enhanced growth can be adaptive when plants face water shortages and/or extreme temperatures, depending on the specific environmental conditions and plant genetic background. In reference to this conundrum, a review by Dolferus [54] on abiotic stress tolerance is entitled, "To grow or not to grow: a stressful decision for plants." However, despite these alternative responses depending on specific circumstances, some general trends in plant growth under either cold temperature or heat/drought can be identified. One ubiquitous plant response in a diversity of stressful environments is increased ROS production [55]. As stated above, ROS can either stimulate or inhibit growth, and plant growth itself can likewise either be accelerated or stunted in stressful environments. For example, in montane ecosystems with frozen soils, evergreens typically arrest growth and downregulate photosynthesis during winter [56,57]. This downregulation of photosynthesis is helpful to prevent the opening of stomates on intermittent winter days with mild air temperatures when there is no opportunity to replace water lost from leaves or needles. In contrast to these evergreens that persist throughout entire harsh seasons in a state of suspended activity, herbaceous biennials and winter annuals grow only where soil water is available on intermittently warm days, upregulate photosynthetic capacity under cool temperature, and take full advantage of mild winter days to produce carbohydrates for immediate or future growth. Similar contrasts in growth responses are seen in desert environments (see [58]). Many evergreens arrest growth and photosynthesis as summer heat/drought set in. In contrast, desert ephemerals, which germinate and grow rapidly during a short rainy season, accelerate growth and complete their lifecycle before drought sets in.

\subsection{CBFs and the Phenotype of Cool-Grown Winter Annuals}

Under cool conditions in autumn and winter, winter annuals typically slow their vegetative growth and upregulate photosynthetic capacity [7,15-17]. This upregulation of photosynthetic capacity allows maintenance of photosynthesis under prevailing cool temperature, and record rates of photosynthesis under warm temperature (see [59]). This photosynthetic upregulation in overwintering herbaceous species allows continued carbon gain in winter, supporting exceptionally high photosynthesis rates during intermittent warm, high-light periods, and thereby contributing to accelerated growth and flowering in the spring.

Hüner et al. [16] discussed the cool-temperature-induced photosynthetic upregulation of winter annuals in the context of the CBF regulon, and suggested that enhancing the capability for bursts of photosynthetic activity in crops would accelerate growth during the spring season with moderately cool temperatures, high water availability, and high water-use efficiency. Early sowing of summer annuals has been shown to provide relief by improving water availability [60] as well as seed yield and quality [61] in geographic areas with intense summer heat and drought. However, moving agriculture to higher latitude or altitude with less summer heat and drought, or early sowing of summer crops, exposes these plants to periods of low temperature. The benefits of early sowing of summer annuals might thus be enhanced by targeting the CBF/DREB system in efforts to improve photosynthetic performance under cool temperature.

\subsection{Example of a Gene Capable of Orchestrating either Reduced or Accelerated Growth under Heat/Drought}

As stated above, plant adaptation to hot/dry conditions can involve either reduced growth or accelerated growth and early flowering. One gene involved in both of these strategies, the FRIGIDA (FRI) gene, was studied by Lovell et al. [62] in A. thaliana. Low FRI expression was associated with a strategy of drought escape, consisting of rapid growth and early flowering, allowing for completion of the life cycle before peak drought/heat. On the other hand, high FRI expression was associated with slowed growth, reduced use of water per plant, and delayed flowering. The control of flowering time also involves a number of other genes (see [63]), the discussion of which is beyond the scope of this review. 


\section{Redox Regulation and Photoprotection}

\subsection{The Chloroplast Transduces the State of the Environment into Redox Signals}

The redox-signaling networks that modulate plant growth and development receive input from plant sensors that gauge opportunity or threat posed by the environment [47-49]. In the green leaf, the chloroplast plays a key role in sensing limitations posed by unfavorable temperatures or light intensities, drought, and other conditions as described below. Any and all of these environmental conditions affect the chloroplast's balance between absorbed and utilized light energy. Limitations to photosynthesis or plant growth lower the fraction of absorbed light that can be utilized in these processes, and thereby increase the level of excess absorbed light. The resulting excess excitation energy can produce ROS, which provides input into the cellular redox-signaling network [64,65]. Among the targets of redox modulation are the CBF/DREB regulons (see Section 2.2).

The chloroplast's many antioxidation systems modulate the level of excess light, ROS production, and redox signal generation. For example, photoprotective, preemptive thermal dissipation of excess excitation energy and ROS-detoxifying antioxidants like tocopherols lower the levels of ROS and their derivatives [66]. In Section 4, we describe ecotypic differences in the capacity for thermal energy dissipation and foliar tocopherol levels between locally adapted $A$. thaliana ecotypes grown under common conditions, which indicates genetic differences in the extent of redox-signal generation.

\subsection{Redox Signals Modulate Vascular Infrastructure}

Studies with tocopherol-deficient mutants have established a link between tocopherol-dependent signaling and the foliar vasculature [67-72]. Tocopherol levels affected the specific organization of water and sugar conduits (Table 1), but impacted neither total sugar- and water-transport capacity nor photosynthetic capacity (not shown; see [72]). Tocopherol-deficient mutant had more but narrower water conduits than the Col-0 wild-type (Table 1; [72]), which would be expected to decrease cavitation risk under high evaporative demand, thereby increasing high-temperature tolerance [73,74] and maintaining stomatal opening $[75,76]$. These adjustments thus bolstered high-temperature tolerance with no penalty for photosynthesis. It is possible that plant lines with augmented tocopherol levels would be more prone to cavitation events under high temperature. Efforts to engineer plant antioxidant levels need to take such responses into consideration.

Table 1. Anatomical features of water-transporting xylem conduits in the leaves of wild-type (Col-0)

A. thaliana and a tocopherol-deficient mutant (vte1) grown at hot temperatures $\left(36^{\circ} \mathrm{C}\right)$.

\begin{tabular}{ccc}
\hline & Water Conduit Number per Vein * & ${\text { Individual Water Conduit Cross-Sectional Area, } \boldsymbol{\mu m}^{2}{ }^{* *}}$ \\
\hline Col-0 wild-type & $8.0 \pm 0.5$ & $23.8 \pm 1.7$ \\
Tocopherol-deficient vte1 mutant & $10.5 \pm 0.4$ & $20.5 \pm 0.6$ \\
\hline
\end{tabular}

Mean values \pm standard errors $(n=4$ to 5$)$; significant differences $\left(t\right.$-test) indicated by asterisks- ${ }^{*}=p<0.05$,

$* *=p<0.01$. Data from Stewart et al. [71].

It should be noted that vascular organization may not only affect plant tolerance to abiotic stress, but also to the many pathogens that spread through the vasculature (such as viruses, bacteria, and fungi; [77-79]). Modulation of foliar vascular organization thus has the potential to serve in co-optimizing plant productivity and abiotic and biotic stress tolerance.

\subsection{Manipulation of Thermal Energy Dissipation and Plant Growth: Photon-Capture Efficiency and Redox Regulation}

Leaves exposed to full sunlight absorb more light than they can utilize in photosynthesis, and the potentially harmful excess excitation energy is dissipated via thermal energy dissipation, triggered by increased trans-thylakoid $\mathrm{pH}(\Delta \mathrm{pH} ;$ [80-82]). When the light level absorbed by the leaf is no longer excessive and no other stresses are present, thermal dissipation is disengaged via a drop in $\Delta \mathrm{pH}$ and 
a removal of the xanthophyll pigments involved in dissipation. Leaves engineered for accelerated $\Delta \mathrm{pH}$ abolishment [83] or accelerated removal of energy-dissipating xanthophylls [84] exhibited increased carbon uptake after transitions from high to low light and accumulated significantly more biomass.

Future research should elucidate to what extent this enhanced biomass production is due to increased energy availability as a result of increased photon-capture efficiency, and to what extent growth stimulation may result from increased production of ROS signals that stimulate cell expansion and growth (see above). An association between accelerated plant growth and a decreased emphasis on thermal dissipation and increased emphasis on ROS production is consistent with findings by Esteban et al. [85]. The latter authors conducted a large survey among photosynthetic organisms and revealed an evolutionary trend towards decreased emphasis on thermal energy dissipation by xanthophylls. This trend represents a progression away from preemptive removal of excitation energy towards permitting greater ROS production. Such a progression would speed up return to maximal photon-capture efficiency upon transition to limiting light as well as allow greater levels of growth-stimulating ROS. Comparative eco-physiological studies have identified a greater emphasis on pre-emptive thermal energy dissipation in perennials (and particularly evergreens) compared to annual species [66]. For slow-growing perennials, the penalty of a somewhat lower photon-capture efficiency upon return to limiting light may be minimal, whereas faster-growing annuals with higher growth rates may derive particularly pronounced benefit from an accelerated return to maximal photon-capture efficiency [66].

There may also be natural ecotypic variation in thermal energy dissipation kinetics. Two ecotypes of $A$. thaliana from Sweden and Italy vary in the degree to which they adjust to low versus high growth light intensity ([86]; see also Section 4.6 below). The Italian ecotype had a superior ability to acclimate to low growth light intensity and high temperature, exhibiting higher growth rates under both conditions $[76,86,87]$. Our preliminary observations also indicate that speed and extent of the relaxation of thermal energy dissipation subsequent to high-light exposure are greater in the Italian ecotype [88]. In addition, two genes that speed up transition from high thermal energy dissipation rates to maximal photochemical efficiency were expressed at higher levels in the Italian ecotype under low light and warm temperature [89]. These genes encode zeaxanthin epoxidase, which functions in the removal of dissipating xanthophylls, and the $\mathrm{K}^{+} / \mathrm{H}^{+}$antiporter KEA3 that helps abolish $\Delta \mathrm{pH}$, the overexpression of either of which resulted in greater biomass production in tobacco $[83,84]$.

\section{Natural Populations Illustrate How Trade-Offs in Performance under Cool versus Hot Temperature Can Be Minimized}

\subsection{Arabidopsis thaliana Ecotypes from Sweden and Italy Show Differential Adaptation Patterns and CBF Expression}

The model species $A$. thaliana is a winter annual with a natural geographic range covering climates with very cold to warm temperatures. A comparison of ecotypes from Sweden and Italy illustrates the links between natural genetic variation in CBF transcription factors and differential acclimation of plant features supporting superior photosynthetic performance in contrasting environments. While these two ecotypes originate from different latitudes and temperature regimes (see [75]), their sites of origin are very similar with respect to distance from coast and altitude [90]. These ecotypes differ in their acclimatory responsiveness to growth temperature environment (hot versus cold) and light environment (limiting versus high light), and especially in the extent to which they switch off the trademark cool-temperature/high-light phenotype of winter annuals when grown under common controlled conditions, as is detailed below. Moreover, in their respective native habitats, the Italian ecotype grows rapidly and flowers early in spring, whereas the Swedish ecotype grows and flowers later in early summer [90] (for a host of other phenotypic differences, see below). This difference in flowering time between the ecotypes can be viewed in the context of the accelerated growth and flowering discussed in Section 2.3 for genotypes adapted to habitats with warm/dry summers. 
CBF2/DREB1C was initially thought to negatively regulate CBF1/DREB1B and CBF3/DREB1A expression and reduce freezing tolerance in A. thaliana [91]. However, recent evidence suggests CBF2 may, in fact, be more important for cold acclimation than CBF1 and CBF3 (see, e.g., [92] and Discussion therein). These latter findings are consistent with those from studies on wild populations of $A$. thaliana. The CBF2 transcription factor is nonfunctional in the Italian ecotype [93], as well as in a number of other $A$. thaliana ecotypes from warm climates ([32,34]; see also [94]). Reduced tolerance of the Italian ecotype to deep-freeze events compared to the Swedish ecotype has been linked to the Italian ecotype's nonfunctional CBF2 through both quantitative trait loci mapping ([35]; see also [95]) and transgenic [93] approaches. However, the Italian ecotype does exhibit substantial upregulation of photosynthetic capacity under cool temperature $[75,76]$ and, furthermore, switches off the cool-temperature/high-light phenotype more effectively than the Swedish ecotype under either hot temperature or low light $([76,86,87,96]$; for details, see below). Over a considerable range of growth temperatures between $8{ }^{\circ} \mathrm{C}$ and $35^{\circ} \mathrm{C}$, the Italian ecotype is thus able to minimize trade-offs.

\subsection{The Cool-Temperature Phenotype of Winter Annuals Is Reminiscent of a High-Light Phenotype}

Some of the mechanisms that underlie acclimation to cold temperature in winter annuals also underlie acclimation to high light $[15,17,97]$. In plants grown under either cool temperature or high light, the Swedish ecotype exhibits thicker leaves, higher chlorophyll levels, and a higher photosynthetic capacity on a leaf area basis compared to the Italian ecotype.

Concomitant increases of the number of chloroplast-rich palisade layers and leaf vascular capacity led to the coordinated upregulation of light collection, carbon uptake, and sugar export under cool growth temperature and/or high growth light intensity $[71,75,98]$. The exceptionally high photosynthetic capacity in cool-grown plants of the Swedish ecotype $[59,75,76]$ is conducive for taking advantage of narrow windows of opportunity for carbon gain during warm, high-light periods during mild winter and spring days.

\subsection{An Experimental Design Suitable to Identify On-Off Switches That Minimize Penalties}

To be able to identify on/off switches and their genetic basis, experimental design must test for genotypic differences in the degree of responsiveness to environmental conditions. In order to quantify the effect of genetic adaptation on phenotypic plasticity, genotypes must be compared under more than a single environmental condition. Choosing contrasting points on the spectrum of nonlethal conditions is helpful to reveal ecotypic differences in the ability to switch responses on and off. To compare the extent of their adjustment to different temperature and light environments, the Italian and Swedish ecotypes were grown under low versus high light (under moderate growth temperature), and also under cool versus hot temperature (under moderate growth light intensity; Figure 3). As detailed below, this approach revealed a host of informative ecotypic differences in the degree of up- or downregulation of key plant features and associated genes.

An additional aspect of experimental design concerns plant source-sink balance. Ecotypic differences in phenotypic adjustment in anatomy, morphology, and photosynthetic performance would be expected to be masked by plant growth under sink-limiting conditions that do not permit full expression of potential plant activity under the environmental conditions of interest. Growth of plants in large rooting volumes with an adequate supply of water and nutrients, and resulting low levels of sink limitation, facilitates identification of ecotypic differences in photosynthetic capacity (see discussion in [75,76]).

The following sections present a synopsis of findings from our group's approach to identify trade-offs between adaptation to low versus high growth light intensity and cold versus hot growth temperature. We review how these trade-offs can be minimized in the example of the Swedish and Italian ecotypes of $A$. thaliana, with attention to plant growth, involvement of redox state and CBF, and the foliar vasculature's role in facilitating whole-plant source-sink relationships and optimizing photosynthetic performance. 


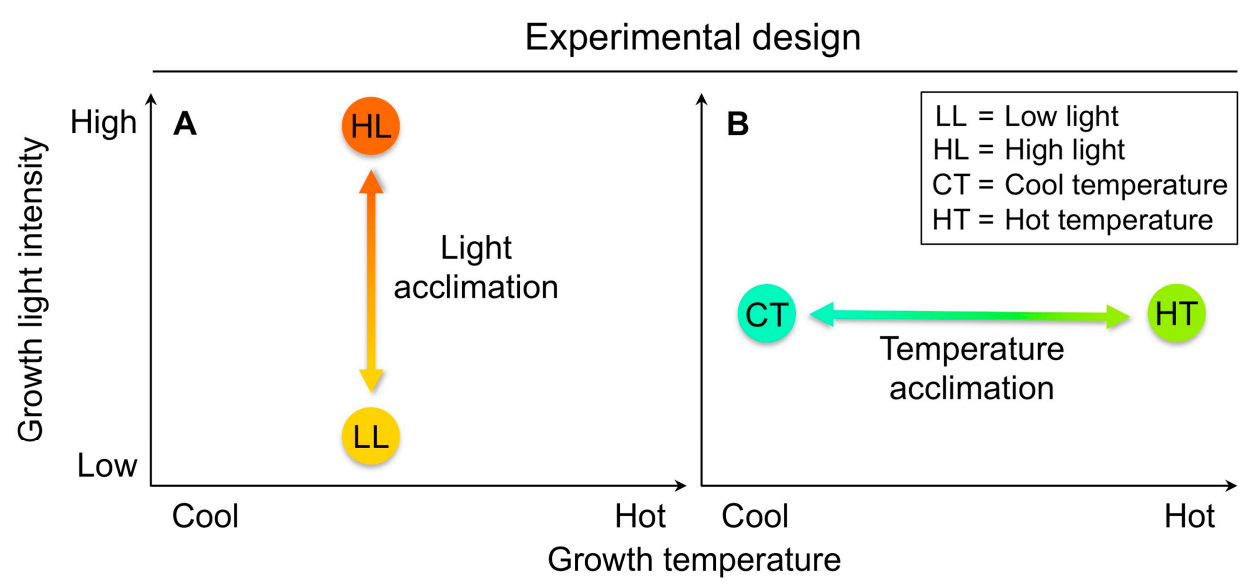

Figure 3. Schematic depiction of the experimental design used to assess (A) light acclimation and (B) temperature acclimation of phenotypic traits (see e.g., Stewart et al. [71]). LL, HL—growth light intensities of 100 and $1000 \mu \mathrm{mol}$ photons $\mathrm{m}^{-2} \cdot \mathrm{s}^{-1}$, respectively, at a leaf temperature of $20^{\circ} \mathrm{C}$ during the light period; CT, HT-leaf temperatures of $14{ }^{\circ} \mathrm{C}$ and $36{ }^{\circ} \mathrm{C}$, respectively, under a growth light intensity of $400 \mu \mathrm{mol}$ photons $\mathrm{m}^{-2} \cdot \mathrm{s}^{-1}$.

\subsection{Differential Adjustment of Leaf Form and Function in Swedish and Italian Ecotypes}

While the Italian ecotype adjusts effectively to hot-temperature or low-light environments by switching off the trademark leaf-morphological responses governing acclimation to cool temperature or high light in this winter annual, the Swedish ecotype exhibits reduced growth under both conditions [76,86]. The Italian ecotype thereby minimizes growth penalties in low-light or hot-temperature environments.

\subsubsection{Different Growth Rates in Swedish and Italian Ecotypes}

Much smaller rosettes (Figure 4) with lower biomass are produced by the Swedish versus the Italian ecotype under either hot growth temperature [76] or low growth light intensity [86]. The faster growth of the Italian ecotype under hot temperature could, once again, be viewed as serving in heat/drought escape (see Section 2.3 above).

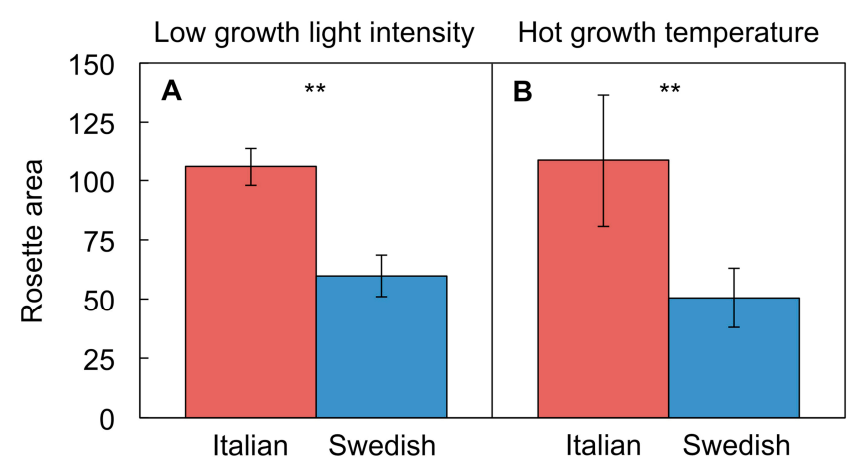

Figure 4. Rosette area (total light-exposed leaf area per plant) of Italian and Swedish ecotypes of $A$. thaliana grown (A) under low light intensity $\left(100 \mu \mathrm{mol}\right.$ photons $\left.\mathrm{m}^{-2} \cdot \mathrm{s}^{-1}\right)$ at a moderate leaf temperature $\left(20^{\circ} \mathrm{C}\right)$ and $(\mathbf{B})$ at a hot leaf temperature $\left(36^{\circ} \mathrm{C}\right)$ under moderate light intensity $\left(400 \mu \mathrm{mol}\right.$ photons $\left.\mathrm{m}^{-2} \cdot \mathrm{s}^{-1}\right)$. Mean values \pm standard deviations $(n=3$ to 4$)$; significant differences ( $t$-test) indicated by asterisks- ${ }^{* *}=p<0.01$. Data from Stewart et al. (A) [86] and (B) [76]. The latter references also include images of plants grown under the various conditions. 


\subsubsection{Differential Antioxidant Levels between Swedish and Italian Ecotypes}

Since ROS can stimulate leaf expansion [52], it is of interest whether the Italian ecotype exhibits lower antioxidant levels than the Swedish ecotype. Indeed, the levels of the antioxidant tocopherol are lower in the Italian ecotype under both hot growth temperature and low growth light intensity compared to the Swedish ecotype [76,87]. In addition, the maximal capacity for removal of excess excitation energy via thermal dissipation, which counteracts ROS production, is lower in the Italian ecotype grown under short daily periods of high light [87]. Similarly, Oakley et al. [99] also found lower levels of thermal energy dissipation in the Italian versus the Swedish ecotype upon transfer to cold temperature. Future research should quantify the levels of ROS in the two ecotypes under various growth conditions, and also elucidate the genetic basis of altered antioxidant levels in the Italian ecotype and their link to superior growth and rosette expansion under certain conditions.

\subsubsection{Differential CBF Expression between Swedish and Italian Ecotypes}

The known dysfunction of the CBF2 transcription factor in the Italian ecotype is associated with differences in gene expression of $C B F 1, C B F 2$, and $C B F 3$ (Figure 5). Figure 5 shows relative CBF1-3 gene expression levels for the Italian versus Swedish ecotype under low growth light intensity and warm temperature, where the rosette-expansion rate is much higher in the Italian ecotype (Figure 4). The higher CBF1-3 expression under low light in the Swedish ecotype is likely the reason for the stunted growth of this ecotype under this condition. It can be concluded that the Italian ecotype possesses a superior ability to turn off $C B F$ gene expression under low light at warm temperature. It should be noted that the CBF2 gene is still expressed (and responsive to, e.g., cold temperatures) in the Italian ecotype, but its $\mathrm{CBF} 2$ protein is not functional due to a mutation that results in a premature stop codon [93].

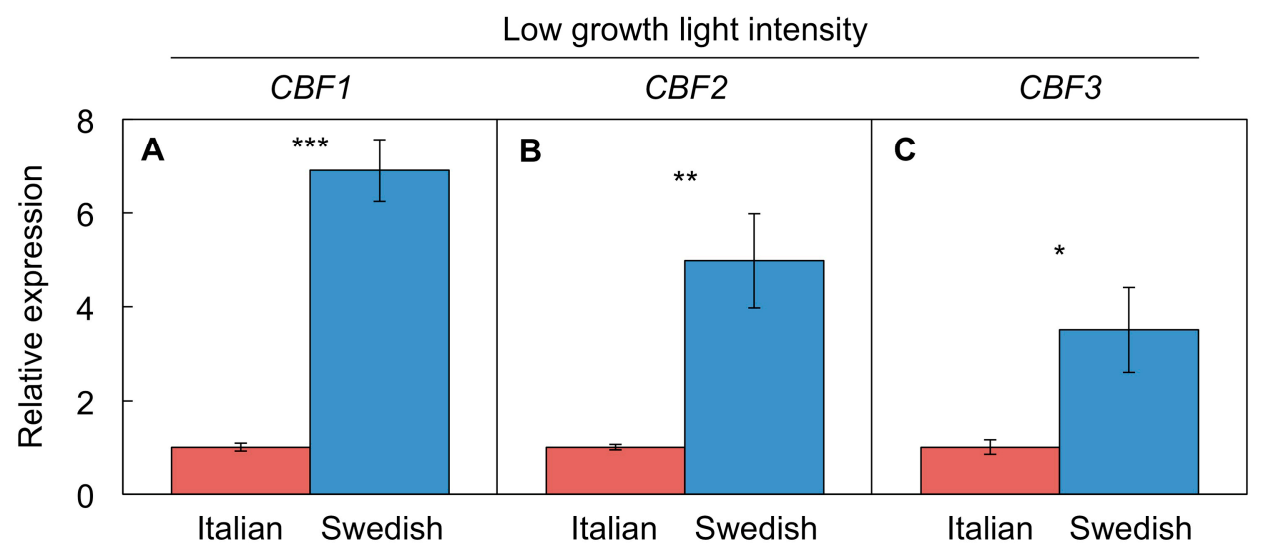

Figure 5. Relative expression (with mean transcript values for the Italian ecotype set to 1) of (A) CBF1 (AT4G25490), (B) CBF2 (AT4G25480), and (C) CBF3 (AT4G25470) genes from leaves of Italian (Castelnuovo-12 [ABRC stock number: CS98761], sub-line 24) and Swedish (Rodasen-47 [ABRC stock number: CS98762], sub-line 29) ecotypes of $A$. thaliana grown under low light intensity (9-h photoperiod of $100 \mu \mathrm{mol}$ photons $\left.\mathrm{m}^{-2} \cdot \mathrm{s}^{-1}\right)$ at warm temperature $\left(25^{\circ} \mathrm{C} / 20^{\circ} \mathrm{C}\right.$ [light/dark] air temperature). Mean values \pm standard deviation $(n=4)$; significant differences $\left(t\right.$-test) indicated by asterisks $-^{*}=p<0.05$, ${ }^{* *}=p<0.01,{ }^{* * *}=p<0.001$. Leaf discs of $0.73 \mathrm{~cm}^{2}$ were homogenized in liquid nitrogen by bead beating and RNA was extracted and DNase-treated (Qiagen RNeasy Plant Mini Kit). cDNA synthesis was performed with $2 \mu \mathrm{g}$ of DNase-treated RNA per sample (Qiagen Omniscript cDNA Synthesis $\mathrm{Kit}$ ). Due to the sequence similarity of the three CBF genes, qPCR primers were designed using the NCBI Primer-BLAST Tool in order to minimize off-target amplification of paralogous genes. qPCR was performed with $40 \mathrm{ng}$ of cDNA per sample (Applied Biosystem's Fast Sybr Green Master Mix) and the housekeeping gene UBC21 (AT5G25760) was used as a control. 


\subsubsection{Ability to Switch Off Other Features of the Cool-Temperature/High-Light Phenotype}

In addition to the growth features shown above, the Swedish ecotype also constitutively maintains other high-light characteristics in low light, such as a higher photosynthetic capacity and greater volumes of sugar-export and water-import conduits [86,87], while the Italian ecotype is able to switch off this phenotype more effectively (Figure 6). It is attractive to assume that this differential phenotypic adjustment is associated with the differential $C B F$ expression and differential antioxidant levels shown above.

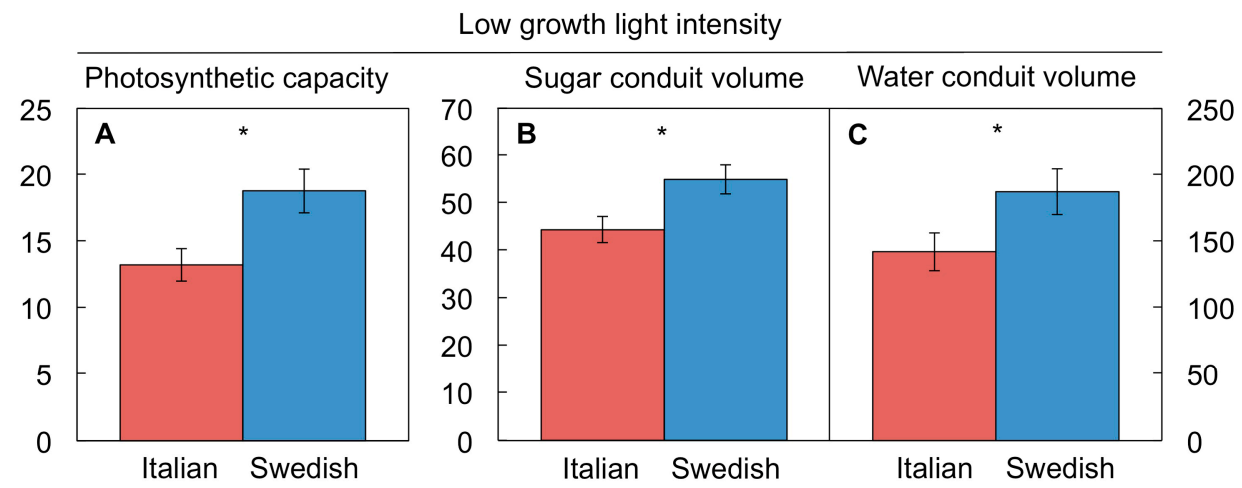

Figure 6. (A) Photosynthetic capacity $\left(\mu \mathrm{mol} \mathrm{O} \mathrm{O}^{-2} \cdot \mathrm{s}^{-1}\right)$ and volumes $\left(\mathrm{mm}^{3} \mathrm{~m}^{-2}\right)$ of minor-vein (B) sugar-transporting and (C) water-transporting conduits in leaves of Italian and Swedish ecotypes of A. thaliana grown under low light intensity $\left(100 \mu \mathrm{mol}\right.$ photons $\left.\mathrm{m}^{-2} \cdot \mathrm{s}^{-1}\right)$ at moderate leaf temperature $\left(20^{\circ} \mathrm{C}\right)$. Mean values \pm standard deviations $(n=4)$; significant differences $(t$-test) indicated by asterisks- ${ }^{*}=p<0.05$. Data from Stewart et al. [86].

4.5. A Key Role for Vascular Adjustment: High Photosynthesis Rates Supported by Improved Sugar Removal at Cool Temperature and Improved Water Delivery at Hot Temperature

\subsubsection{Coordination of Photosynthetic Productivity with Sugar and Water Transport}

A leaf's photosynthetic capacity is coordinated with the capacity for sugar and water transport $([59,100]$; see Figure 1 above for a schematic depiction). Leaves must import sufficient water to compensate for water lost during photosynthetic $\mathrm{CO}_{2}$ uptake and keep the stomates open [11,12]. On the other hand, the expedient removal of sugar produced in photosynthesis is important to avoid carbohydrate back-up in leaves and photosynthetic downregulation by sugar signals $[8,101,102]$.

\subsubsection{Upregulation of Sugar-Export Capacity under Cool Growth Temperature}

Challenges to photosynthetic activity under cool temperature include reduced enzyme activity and resulting decreases in the carbon-fixation rate and in transporter-dependent loading of sugar into sugar-export conduits as well as increases in phloem-sap viscosity. The cool-temperature-induced limitations to foliar sugar export (and feedback inhibition of photosynthesis) can be overcome by upregulation of a suite of biochemical and infrastructural features $[75,103]$ that support sugar-export capacity and prevent the repression of photosynthetic genes. In other words, limiting photosynthate-export capacity from a source leaf can be thought of as a bottleneck and a type of sink limitation close to home.

Arabidopsis thaliana leaves load sugars into sugar-exporting phloem conduits via membrane transporters (see [104]). An increased loading-cell surface area can accommodate more membrane transporters and thereby counteract the inhibitory effect of decreasing temperature on transporter activity. When grown under cool temperature, $A$. thaliana upregulates the number of sugar-loading cells as well as phloem-cell-wall ingrowths that magnify cell membrane area in concert with photosynthetic capacity (Figure 7). The greater upregulation of loading-cell number and cell-wall ingrowths in the 
Swedish versus the Italian ecotype can serve as a proxy for a greater upregulation of loading-cell surface area (Figure 8; [75]).

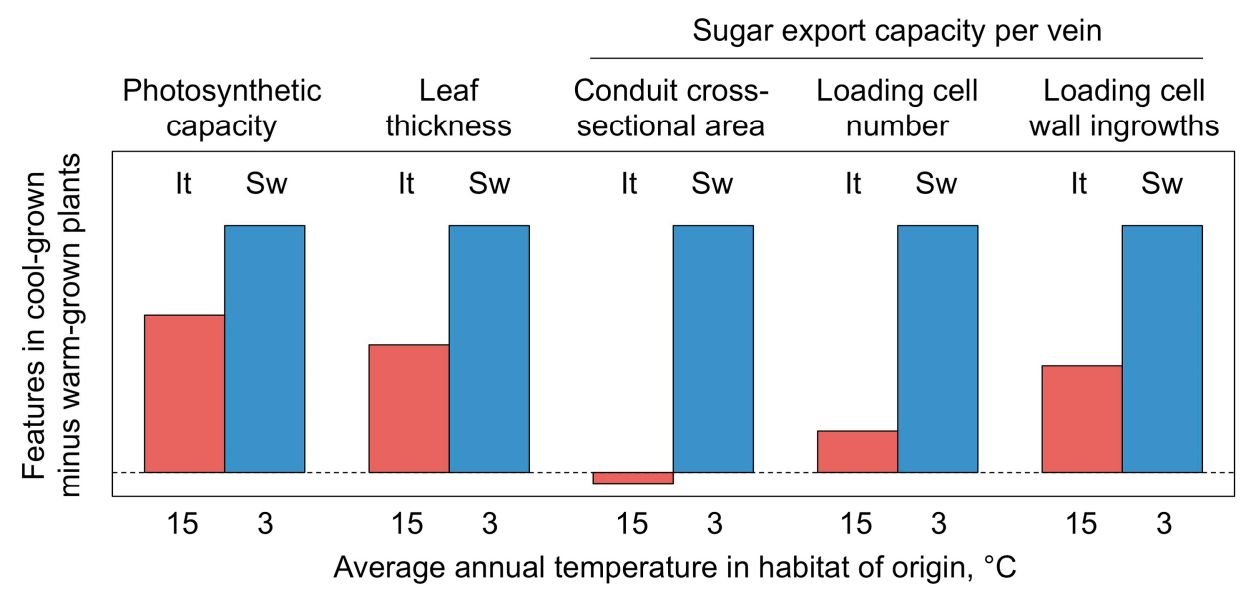

Figure 7. Differences in leaf and minor-vein features of Italian (It) and Swedish (Sw) ecotypes of A. thaliana grown at cool $\left(14{ }^{\circ} \mathrm{C}\right)$ versus warm $\left(36^{\circ} \mathrm{C}\right)$ leaf temperatures under a moderate light intensity of $400 \mu \mathrm{mol}$ photons $\mathrm{m}^{-2} \cdot \mathrm{s}^{-1}$, in relation to average annual temperatures of the locations from which the ecotypes originated. Based on data from Adams et al. [75].

Envisioned sugar-loading-cell area available for placement of sugar transporters

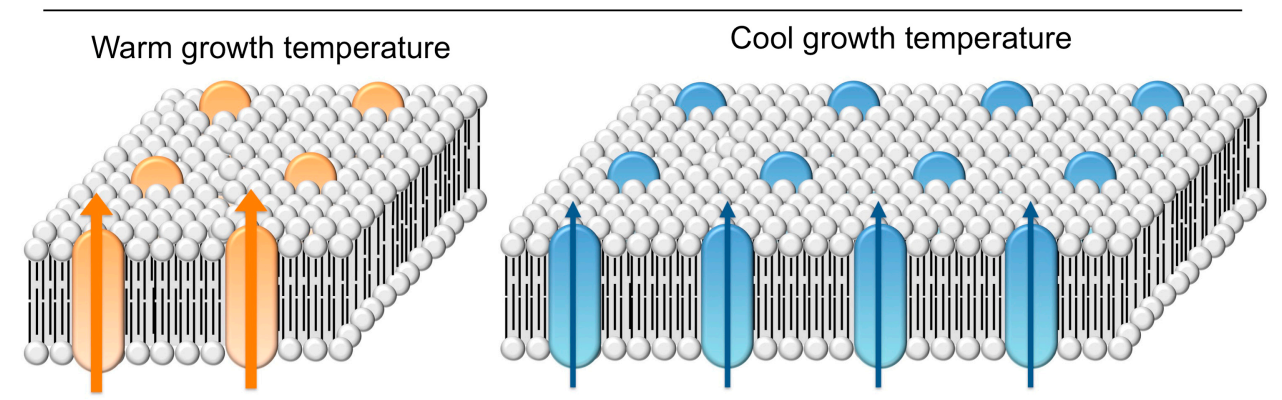

Figure 8. Schematic depiction of an increased membrane surface area of sugar-loading phloem cells, with a greater number of sugar transporters and ATPases that can counteract the reduced activity of such transporters (indicated by arrow width) in winter annual apoplastic loaders at cool versus warm growth temperatures. Based on data from Adams et al. [75,103].

In addition, to compensate for increased viscosity of the sugar-laden sap exported from leaves at low temperature (see Discussion in [105]), the combined volume of sugar-export conduits can be increased, which helps avoid foliar sugar accumulation and photosynthetic downregulation [101,102]. Figure 7 shows greater upregulation of sugar-conduit cross-sectional area, as a proxy for sugar-export-conduit volume, in the Swedish versus the Italian ecotype under cool versus hot growth temperature ([75]; see also [76]). These adjustments can support the maintenance of photosynthesis rate under prevailing cool temperature and result in record rates of photosynthesis under warmer temperatures at midday.

\subsubsection{Upregulation of Foliar Water-Import Capacity under Hot Growth Temperature}

The maintenance of high photosynthetic productivity under hot temperature requires increased water delivery to the leaf to compensate for enhanced evaporative water loss and support continued stomatal opening and carbon gain. This link between water delivery to leaves and stomatal opening is described in models on the hydraulic efficiency-photosynthesis connection $[11,12,106]$. In A. thaliana grown under hot temperature, water delivery to leaves is increased via increased foliar vein density 
and an increased ratio of water-import to sugar-export capacity, accompanied by an increased ratio of transpiration to photosynthesis $[71,75,76]$.

The transcription factor DREB2C, implicated in thermotolerance in A. thaliana [26,107], is most heavily expressed in the vasculature in response to heat stress [108], and may therefore play a role in the upregulation of foliar water-import capacity. A particularly pronounced increase in vein density and in the number of water conduits per vein under hot growth temperature was seen in an A. thaliana ecotype from a location with relatively low levels of annual precipitation $[75,76]$. This adaptation strategy is unique to annual species. In contrast, woody perennials typically restrict water delivery to the leaves under drought/heat through development of narrower conduits that are less susceptible to cavitation. For example, in a study on a range of woody perennials, Blackman et al. [109] found leaves with narrow, thick-walled water conduits to be advantageous under drought stress. Moreover, Pfautsch et al. [110] found a strong inverse relationship between water-conduit diameter and aridity across multiple Eucalyptus tree species in Australia.

\subsection{Leaf Acclimation to Light Environment Defines Sun-Loving and Shade-Loving Genotypes}

\subsubsection{Adjustment of Leaf Size and Thickness}

Plant acclimation to high-light environments typically involves thicker leaves [111]. In such environments, enough light is available to penetrate into the lower expanses of thick leaves that display chloroplasts and chlorophyll in a vertical column and require high light intensities for light saturation of photosynthesis of the self-shaded chloroplasts in the lower portion of the leaf. A survey among tree species found that sun-loving species exhibited greater upregulation of photosynthesis, leaf thickness, and hydraulic conductivity under high compared to low growth light intensity [112].

Conversely, larger leaf areas are often seen in plants acclimated to shaded environments $[111,113]$. Larger leaves allow for display of chloroplasts and chlorophyll horizontally, which minimizes competition for light by self-shading. Interspecies comparison revealed similar differences between shade- and sun-loving species, with greater leaf areas per plant and greater absolute growth rates in low light in highly shade-tolerant species [114].

The differential trends in acclimation to light environment seen in the ecotype pair from Sweden and Italy identify the Swedish ecotype as sun-loving and shade-intolerant and the Italian ecotype as shade-tolerant. Just as was seen under hot versus cool growth temperatures [76], the Swedish ecotype did not turn off the cool-temperature/high-light phenotype as effectively as the Italian ecotype under low growth light intensity either (Figure 6; [86]). Low-light-grown plants of the Swedish ecotype still had somewhat thicker leaves and much smaller rosettes than the Italian ecotype.

\subsubsection{Adjustment of Leaf Vascular Anatomy}

The volume of both water and sugar conduits was greater in leaves grown under high versus low light $[71,86]$. This is expected since higher photosynthesis rates in a high-light environment create a greater demand for both sugar export and water import. Once again, the degree of this acclimation was more pronounced in the Swedish versus the Italian ecotype. Specifically, high-light-grown leaves of the Swedish ecotype exhibited a greater photosynthetic capacity and greater leaf mass per area, a greater number of chloroplast-rich palisade cell layers, as well as greater numbers of sugar-loading phloem cells, larger sugar-export conduits, and larger total volumes of water conduits [86]. Conversely, the Italian ecotype exhibited superior acclimation to low growth light intensity, with larger rosette areas and greater aboveground biomass accumulation in low-light-grown plants $[86,87]$.

\subsection{What Is Known about the Regulators of Vascular Organization}

Little is known about an involvement of CBF/DREB in leaf vascular organization, except for DREB2C expression in the vasculature under heat stress (see above). Future studies should give attention to a possible DREB involvement in a putative greater xylem-to-phloem capacity in 
drought-tolerant crop varieties that exhibit larger root volumes, greater access to water in the soil, and higher stomatal conductance and photosynthesis rates than drought-sensitive varieties [115].

As discussed above, the CBF/DREB regulon includes many genes involved in various aspects of temperature adaptation and interacts strongly with phytohormones and redox messengers. Mutant studies have revealed involvement of both phytohormones and antioxidants in the modulation of vascular development. For example, auxin plays a major role in leaf venation patterning [116,117]. Foliar vein density, hydraulic conductance, and $\mathrm{CO}_{2}$ and water exchange was reduced in auxin-deficient mutants compared to wild-type [118]. Vascular acclimation also responds to tocopherol level [69]; tocopherol deficiency was associated with an increased proportion of water to sugar conduits at high temperature, as well as higher vein density under some growth conditions [71,72].

\section{From Mechanistic Insight to Crop Improvement}

We hope that the insight summarized here will contribute to future efforts in crop improvement. Combining eco-physiological work with "-omics" tools and targeted gene editing should also be able to address the questions posed here. Such integrative approaches can be added to the many ongoing efforts to improve plant performance in stressful environments using other key regulators, such as stress-responsive NAC (SNAC) [119], homeodomain (HD)-START [120], nuclear factor-Y (NF-Y) [121], and HARDY [122] transcription factors (for a review of these transcription factors as well as CBFs/DREBs in the context of drought stress tolerance, see [123]).

\section{Conclusions}

1. To provide guidance for future germplasm screening, genomics-directed breeding, and gene editing, studies into adaptive traits should give attention to the whole-plant source-sink relationship and a range of relevant environmental conditions.

2. Superior plant productivity depends on distinct plant features in different environments, and could be custom-designed for specific local contexts using environmentally induced gene regulators, such as CBF/DREB transcription factors, that coordinate multiple aspects of plant function.

3. Arabidopsis thaliana remains an ideal model organism. In terms of eco-physiology, it occupies a range of native habitats, with different ecotypes manifesting distinct functionality under controlled growth conditions. On the molecular side, over a thousand sequenced A. thaliana genomes are available for transformation of selected ecotypes via precision gene editing.

Acknowledgments: We thank Jon Ågren and Douglas W. Schemske for providing seed of the Swedish and Italian ecotypes of $A$. thaliana. This work was supported by the National Science Foundation (Award Number DEB-1022236 to BD-A and WWA), the Life Sciences Research Foundation Fellowship to Kris Niyogi funded by the Gordon and Betty Moore Foundation, the University of Colorado at Boulder, and the University of California at Berkeley.

Conflicts of Interest: The authors declare no conflict of interest.

\section{Abbreviations}

$\begin{array}{ll}\text { CBF } & \text { C-repeat binding factor } \\ \mathrm{CT} & \text { cool growth temperature } \\ \Delta \mathrm{pH} & \text { trans-thylakoid pH gradient } \\ \text { DREB } & \text { dehydration-responsive element-binding factor } \\ \mathrm{HL} & \text { high growth light intensity } \\ \mathrm{HT} & \text { hot growth temperature } \\ \text { LL } & \text { low growth light intensity } \\ \text { NPQ } & \text { non-photochemical quenching of chlorophyll fluorescence } \\ \text { ROS } & \text { reactive oxygen species }\end{array}$




\section{References}

1. Long, S.P.; Ainsworth, E.A.; Leakey, A.D.B.; Nösberger, J.; Ort, D.R. Food for thought: Lower-than-expected crop yield stimulation with rising $\mathrm{CO}_{2}$ concentrations. Science 2006, 312, 1918-1921. [CrossRef] [PubMed]

2. Long, S.P.; Marshall-Colon, A.; Zhu, X.-G. Meeting the global food demand of the future by engineering crop photosynthesis and yield potential. Cell 2015, 161, 56-66. [CrossRef] [PubMed]

3. Jaglo-Ottosen, K.R.; Gilmour, S.J.; Zarka, D.G.; Schabenberger, O.; Thomashow, M.F. Arabidopsis CBF1 overexpression induces COR genes and enhances freezing tolerance. Science 1998, 280, 104-106. [CrossRef] [PubMed]

4. Larkindale, J.; Hall, J.D.; Knight, M.R.; Vierling, E. Heat stress phenotypes of Arabidopsis mutants implicate multiple signaling pathways in the acquisition of thermotolerance. Plant Phys. 2005, 138, 882-897. [CrossRef] [PubMed]

5. Moellering, E.R.; Muthan, B.; Benning, C. Freezing tolerance in plants requires lipid remodeling at the outer chloroplast membrane. Science 2010, 330, 226-228. [CrossRef] [PubMed]

6. Hong, S.-W.; Lee, U.; Vierling, E. Arabidopsis hot mutants define multiple functions required for acclimation to high temperatures. Plant Physiol. 2003, 132, 757-767. [CrossRef] [PubMed]

7. Demmig-Adams, B.; Stewart, J.J.; Adams, W.W., III. Environmental regulation of photosynthetic capacity: An integrated view. Curr. Opin. Plant Biol. 2017, 37, 34-41. [CrossRef] [PubMed]

8. Paul, M.J.; Foyer, C.H. Sink regulation of photosynthesis. J. Exp. Bot. 2001, 52, 1383-1400. [CrossRef] [PubMed]

9. Ainsworth, E.A.; Bush, D.R. Carbohydrate export from the leaf: A highly regulated process and target to enhance photosynthesis and productivity. Plant Physiol. 2011, 155, 64-69. [CrossRef] [PubMed]

10. Adams, W.W., III; Cohu, C.M.; Muller, O.; Demmig-Adams, B. Foliar phloem infrastructure in support of photosynthesis. Front. Plant Sci. 2013, 4, 194. [CrossRef] [PubMed]

11. Brodribb, T.J.; Feild, T.S.; Jordan, G.J. Leaf maximum photosynthetic rate and venation are linked by hydraulics. Plant Physiol. 2007, 144, 1890-1898. [CrossRef] [PubMed]

12. Scoffoni, C.; Chatelet, D.S.; Pasquet-kok, J.; Rawls, M.; Donoghue, M.J.; Edwards, E.J.; Sack, L. Hyrdaulic basis for the evolution of photosynthetic productivity. Nat. Plants 2016, 2, 16072. [CrossRef] [PubMed]

13. Fahlgren, N.; Gehan, M.A.; Baxter, I. Lights, camera, action: High-throughput plant phenotyping is ready for a close-up. Curr. Opin. Plant Biol. 2015, 24, 93-99. [CrossRef] [PubMed]

14. Pino, M.-T.; Skinner, J.S.; Jeknić, Z.; Hayes, P.M.; Soeldner, A.H.; Thomashow, M.F.; Chen, T.H.H. Ectopic AtCBF1 over-expression enhances freezing tolerance and induces cold acclimation-associated physiological modifications in potato. Plant Cell Environ. 2008, 31, 393-406. [CrossRef] [PubMed]

15. Hüner, N.P.A.; Bode, R.; Dahal, K.; Hollis, L.; Rosso, D.; Krol, M.; Ivanov, A.G. Chloroplast redox imbalance governs phenotypic plasticity: The "grand design of photosynthesis" revisited. Front. Plant Sci. 2012, 3, 255. [CrossRef] [PubMed]

16. Hüner, N.P.A.; Dahal, K.; Kurepin, L.V.; Savitch, L.; Singh, J.; Ivanov, A.G.; Kane, K.; Sarhan, F. Potential for increased photosynthetic performance and crop productivity in response to climate change: Role of CBFs and gibberellic acid. Front. Chem. 2014, 2, 18. [CrossRef] [PubMed]

17. Hüner, N.P.A.; Dahal, K.; Bode, R.; Kurepin, L.V.; Ivanov, A.G. Photosynthetic acclimation, vernalization, crop productivity and 'the grand design of photosynthesis'. J. Plant Physiol. 2016, 203, 29-43. [CrossRef] [PubMed]

18. Kurepin, L.V.; Dahal, K.P.; Savitch, L.V.; Singh, J.; Bode, R.; Ivanov, A.G.; Hurry, V.; Hüner, N.P.A. Role of $\mathrm{CBFs}$ as integrators of chloroplast redox, phytochrome and plant hormone signaling during cold acclimation. Int. J. Mol. Sci. 2013, 14, 12729-12763. [CrossRef] [PubMed]

19. Schramm, F.; Larkindale, J.; Kiehlmann, E.; Ganguli, A.; Englich, G.; Vierling, E.; von Koskull-Döring, P. A cascade of transcription factor DREB2A and heat stress transcription factor HsfA3 regulates the heat stress response of Arabidopsis. Plant J. 2008, 53, 264-274. [CrossRef] [PubMed]

20. Kidokoro, S.; Watanabe, K.; Ohori, T.; Moriwaki, T.; Maruyama, K.; Mizoi, J.; Myint Phyu Sin Htwe, N.; Fujita, Y.; Sekita, S.; Shinozaki, K.; et al. Soybean DREB1/CBF-type transcription factors function in heat and drought as well as cold stress-responsive gene expression. Plant J. 2015, 81, 505-518. [CrossRef] [PubMed]

21. Lata, C.; Prasad, M. Role of DREBs in regulation of abiotic stress responses in plants. J. Exp. Bot. 2011, 62, 4731-4748. [CrossRef] [PubMed] 
22. Khan, M.S. The role of DREB transcription factors in abiotic stress tolerance of plants. Biotechnol. Biotechnol. Equip. 2011, 25, 2433-2442. [CrossRef]

23. Akhtar, M.; Jaiswal, A.; Taj, G.; Jaiswal, J.P.; Qureshi, M.I.; Singh, N.K. DREB1/CBF transcription factors: Their structure, function and role in abiotic stress tolerance in plants. J. Genet. 2012, 91, 385-395. [CrossRef] [PubMed]

24. Agarwal, P.K.; Gupta, K.; Lopato, S.; Agarwal, P. Dehydration responsive element binding transcription factors and their applications for the engineering of stress tolerance. J. Exp. Bot. 2017, 68, 2135-2148. [CrossRef] [PubMed]

25. Thomashow, M.F. Molecular basis of plant cold acclimation: Insights gained from studying the CBF cold response pathway. Plant Physiol. 2010, 154, 571-577. [CrossRef] [PubMed]

26. Chen, H.; Hwang, J.E.; Lim, C.J.; Kim, D.Y.; Lee, S.Y.; Lim, C.O. Arabidopsis DREB2C functions as a transcriptional activator of HsfA3 during the heat stress response. Biochem. Biophys. Res. Commun. 2010, 401, 238-244. [CrossRef] [PubMed]

27. Haake, V.; Cook, D.; Riechmann, J.; Pineda, O.; Thomashow, M.F.; Zhang, J.Z. Transcription factor CBF4 is a regulator of drought adaptation in Arabidopsis. Plant Physiol. 2002, 130, 639-648. [CrossRef] [PubMed]

28. Shavrukov, Y.; Baho, M.; Lopato, S.; Langridge, P. The TaDREB3 transgene transferred by conventional crossings to different genetic backgrounds of bread wheat improves drought tolerance. Plant Biotechnol. J. 2016, 14, 313-322. [CrossRef] [PubMed]

29. Zhu, W.; Ausin, I.; Seleznev, A.; Méndez-Vigo, B.; Picó, F.X.; Sureshkumar, S.; Sundaramoorthi, V.; Bulach, D.; Powell, D.; Seemann, T.; et al. Natural variation identifies ICARUS1, a universal gene required for cell proliferation and growth at high temperatures in Arabidopsis thaliana. PLoS Genet. 2015, 11, e1005085. [CrossRef] [PubMed]

30. Wingler, A. Comparison of signaling interactions determining annual and perennial plant growth in response to low temperature. Front. Plant Sci. 2015, 12, 794. [CrossRef] [PubMed]

31. Kurbidaeva, A.; Novokreshchenova, M.; Ezhova, T. ICE genes in Arabidopsis thaliana: Clinal variation in DNA polymorphism and sequence diversification. Biol. Plant. 2015, 59, 245-252. [CrossRef]

32. Alonso-Blanco, C.; Gomez-Mena, C.; Llorente, F.; Koornneef, M.; Salinas, J.; Martínez-Zapater, J.M. Genetic and molecular analyses of natural variation indicate CBF2 as a candidate gene for underlying freezing tolerance quantitative trait locus in Arabidopsis. Plant Physiol. 2005, 139, 1304-1312. [CrossRef] [PubMed]

33. Gery, C.; Zuther, E.; Schulz, E.; Legoupi, J.; Chauveau, A.; McKhann, H.; Hincha, D.K.; Téoulé, E. Natural variation in the freezing tolerance of Arabidopsis thaliana: Effects of RNAi-induced CBF depletion and QTL localization vary among accessions. Plant Sci. 2011, 180, 12-23. [CrossRef] [PubMed]

34. Kang, J.; Zhang, H.; Sun, T.; Shi, Y.; Wang, J.; Zhang, B.; Wang, Z.; Zhou, Y.; Gu, H. Natural variation of $C$-repeat-binding factor ( $C B F \mathrm{~s}$ ) genes is a major cause of divergence in freezing tolerance among a group of Arabidopsis thaliana populations along the Yangtze River in China. New Phytol. 2013, 199, 1069-1080. [CrossRef] [PubMed]

35. Oakley, C.G.; Ågren, J.; Atchison, R.A.; Schmeske, D.W. QTL mapping of freezing tolerance: Links to fitness and adaptive trade-offs. Mol. Ecol. 2014, 23, 4304-4315. [CrossRef] [PubMed]

36. Hannah, M.A.; Wiese, D.; Freund, S.; Fiehn, O.; Heyer, A.G.; Hincha, D.K. Natural genetic variation of freezing tolerance in Arabidopsis. Plant Physiol. 2006, 142, 98-112. [CrossRef] [PubMed]

37. Le, M.Q.; Engelsberger, W.R.; Hincha, D.K. Natural genetic variation in acclimation capacity at sub-zero temperatures after cold acclimation at $4{ }^{\circ} \mathrm{C}$ in different Arabidopsis thaliana accessions. Cryobiology 2008, 57, 104-112. [CrossRef] [PubMed]

38. Le, M.Q.; Pagter, M.; Hincha, D.K. Global changes in gene expression, assayed by microarray hybridization and quantitative RT-PCR, during acclimation of three Arabidopsis thaliana accessions to sub-zero temperatures after cold acclimation. Plant Mol. Biol. 2015, 87, 1-15. [CrossRef] [PubMed]

39. Usadel, B.; Bläsing, O.E.; Gibon, Y.; Poree, F.; Höhne, M.; Günter, M.; Trethewey, R.; Kamlage, B.; Poorter, H.; Stitt, M. Multilevel genomic analysis of the response of transcripts, enzyme activities and metabolites in Arabidopsis rosettes to a progressive decrease of temperature in the non-freezing range. Plant Cell Environ. 2008, 31, 518-547. [CrossRef] [PubMed]

40. Medina, J.; Catalá, R.; Salinas, J. The CBFs: Three arabidopsis transcription factors to cold acclimate. Plant Sci. 2011, 180, 3-11. [CrossRef] [PubMed] 
41. Zuther, E.; Schulz, E.; Childs, L.H.; Hincha, D.K. Clinal variation in the non-acclimated and cold-acclimated freezing tolerance of Arabidopsis thaliana accessions. Plant Cell Environ. 2012, 35, 1860-1878. [CrossRef] [PubMed]

42. Gilmour, S.J.; Fowler, S.G.; Thomashow, M.F. Arabidopsis transcriptional activators CBF1, CBF2, and CBF3 have matching functional activities. Plant Mol. Biol. 2004, 54, 767-781. [CrossRef] [PubMed]

43. Savitch, L.V.; Allard, G.; Seki, M.; Robert, L.S.; Tinker, N.A.; Huner, N.P.A.; Shinozaki, K.; Singh, J. The effect of overexpression of two Brassica CBF/DREB1-like transcription factors on photosynthetic capacity and freezing tolerance in Brassica napus. Plant Cell Physiol. 2005, 46, 1525-1539. [CrossRef] [PubMed]

44. Bihani, P.; Char, B.; Bhargava, S. Transgenic expression of sorghum DREB2 in rice improves tolerance and yield under water limitation. J. Agric. Sci. 2011, 149, 95-101. [CrossRef]

45. Morran, S.; Eini, O.; Pyvovarenko, T.; Parent, B.; Singh, R.; Ismagul, A.; Eliby, S.; Shirley, N.; Langridge, P.; Lopato, S. Improvement of stress tolerance of wheat and barley by modulation of expression of DREB/CBF factors. Plant Biotechnol. J. 2011, 9, 230-249. [CrossRef] [PubMed]

46. Kovalchuk, N.; Jia, W.; Eini, O.; Morran, S.; Pyvovarenko, T.; Fletcher, S.; Bazanova, N.; Harris, J.; Beck-Oldach, K.; Shavrukov, Y.; et al. Optimization of TaDREB3 gene expression in transgenic barley using cold-inducible promoters. Plant Biotechnol. J. 2013, 11, 659-670. [CrossRef] [PubMed]

47. Foyer, C.H.; Noctor, G. Redox regulation in photosynthetic organisms: Signaling, acclimation, and practical implications. Antioxid. Redox Signal. 2009, 11, 861-905. [CrossRef] [PubMed]

48. Schippers, J.H.M.; Foyer, C.H.; van Dongen, J.T. Redox regulation in shoot growth, SAM maintenance and flowering. Curr. Opin. Plant Biol. 2016, 29, 121-128. [CrossRef] [PubMed]

49. Tognetti, V.B.; Bielach, A.; Hrtyan, M. Redox regulation at the site of primary growth: Auxin, cytokinin and ROS crosstalk. Plant Cell Environ. 2017, 40, 2586-2605. [CrossRef] [PubMed]

50. Demmig-Adams, B.; Cohu, C.M.; Amiard, V.; van Zadelhoff, G.; Veldink, G.A.; Muller, O.; Adams, W.W., III. Emerging trade-offs-Impact of photoprotectants (PsbS, xanthophylls, and vitamin E) on oxylipins as regulators of development and defense. New Phytol. 2013, 197, 720-729. [CrossRef] [PubMed]

51. Srivastava, A.; Redij, T.; Sharma, B.; Suprasanna, P. Interaction between hormone and redox signaling in plants: Divergent pathways and convergent roles. In Mechanism of Plant Hormone Signaling under Stress; Pandey, G.K., Ed.; John Wiley \& Sons, Inc.: Hoboken, NJ, USA, 2017; Part II, pp. 1-22. [CrossRef]

52. Schmidt, R.; Kunkowska, A.B.; Schippers, J.H.M. Role of reactive oxygen species during cell expansion in leaves. Plant Physiol. 2016, 172, 2098-2106. [CrossRef] [PubMed]

53. Mittler, R. ROS are good. Trends Plant Sci. 2017, 22, 11-19. [CrossRef] [PubMed]

54. Dolferus, R. To grow or not to grow: A stressful decision for plants. Plant Sci. 2014, 229, 247-261. [CrossRef] [PubMed]

55. Sewelam, N.; Kazan, K.; Schenk, P.M. Global plant stress signaling: Reactive oxygen species at the cross-road. Front. Plant Sci. 2016, 7, 187. [CrossRef] [PubMed]

56. Monson, R.K.; Sparks, J.P.; Rosenstiel, T.N.; Scott-Denton, L.E.; Huxman, T.E.; Harley, P.C.; Turnipseed, A.A.; Burns, S.P.; Backlund, B.; Hu, J. Climatic influences on net ecosystem $\mathrm{CO}_{2}$ exchange during the transition from wintertime carbon source to springtime carbon sink in a high-elevation, subalpine forest. Oecologia 2005, 146, 130-147. [CrossRef] [PubMed]

57. Zarter, C.R.; Demmig-Adams, B.; Ebbert, V.; Adamska, I.; Adams, W.W., III. Photosynthetic capacity and light harvesting efficiency during the winter-to-spring transition in subalpine conifers. New Phytol. 2006, 172, 283-292. [CrossRef] [PubMed]

58. Adams, W.W., III; Demmig-Adams, B. Lessons from nature: A personal perspective. In Non-Photochemical Quenching and Energy Dissipation in Plants, Algae and Cyanobacteria, Advances in Photosynthesis and Respiration; Demmig-Adams, B., Garab, G., Adams, W.W., III, Govindjee, Eds.; Springer: Dordrecht, The Nertherlands, 2014; Volume 40, pp. 45-72. [CrossRef]

59. Cohu, C.M.; Muller, O.; Stewart, J.J.; Demmig-Adams, B.; Adams, W.W., III. Association between minor loading vein architecture and light- and $\mathrm{CO}_{2}$-saturated rates of photosynthetic oxygen evolution among Arabidopsis thaliana ecotypes from different latitudes. Front. Plant Sci. 2013, 4, 264. [CrossRef] [PubMed]

60. Soriano, M.A.; Orgaz, F.; Villalobos, F.J.; Fereres, E. Efficiency of water use of early plantings of sunflower. Eur. J. Agron. 2004, 21, 465-476. [CrossRef]

61. Anastasi, U.; Cammarata, M.; Abbate, V. Yield potential and oil quality of sunflower (oleic and standard) grown between autumn and summer. Ital. J. Agron. 2000, 4, 23-36. 
62. Lovell, J.T.; Juenger, T.E.; Michaels, S.D.; Lasky, J.R.; Platt, A.; Richards, J.H.; Yu, X.; Easlon, H.M.; Sen, S.; McKay, J.K. Pleiotropy of FRIGIDA enhances the potential for multivariate adaptation. Proc. R. Soc. B. 2013, 280, 20131043. [CrossRef] [PubMed]

63. Grillo, M.A.; Li, C.; Hammond, M.; Wang, L.; Schemske, D.W. Genetic architecture of flowering time differentiation between locally adapted populations of Arabidopsis thaliana. New Phytol. 2013, 197, 1321-1331. [CrossRef] [PubMed]

64. Li, Z.R.; Ahn, T.K.; Avenson, T.J.; Ballotari, M.; Cruz, J.A.; Kramer, D.M.; Bassi, R.; Fleming, G.R.; Keasling, J.D.; Niyogi, K.K. Lutein accumulation in the absence of zeaxanthin restores nonphotochemical quenching in the Arabidopsis thaliana npq1 mutant. Plant Cell 2009, 21, 1798-1812. [CrossRef] [PubMed]

65. Demmig-Adams, B.; Stewart, J.J.; Burch, T.A.; Adams, W.W., III. Insights from placing photosynthetic light harvesting into context. J. Phys. Chem. Lett. 2014, 5, 2880-2889. [CrossRef] [PubMed]

66. Demmig-Adams, B.; Cohu, C.M.; Muller, O.; Adams, W.W., III. Modulation of photosynthetic energy conversion efficiency in nature: From seconds to seasons. Photosynth. Res. 2012, 113, 75-88. [CrossRef] [PubMed]

67. Russin, W.A.; Evert, R.F.; Vanderveer, P.J.; Sharkey, T.D.; Briggs, S.P. Modification of a specific class of plasmodesmata and loss of sucrose export ability in the sucrose export defective1 maize mutant. Plant Cell 1996, 8, 645-658. [CrossRef] [PubMed]

68. Hofius, D.; Hajirezael, M.R.; Geiger, M.; Tschiersch, H.; Melzer, M.; Sonnewald, U. RNAi-mediated tocopherol deficiency impairs photoassimilate export in transgenic potato plants. Plant Physiol. 2004, 135, 1256-1268. [CrossRef] [PubMed]

69. Maeda, H.; Song, W.; Sage, T.L.; DellaPenna, D. Tocopherols play a crucial role in low-temperature adaptation and phloem loading in Arabidopsis. Plant Cell 2006, 18, 2710-2732. [CrossRef] [PubMed]

70. Maeda, H.; Song, W.; Sage, T.L.; DellaPenna, D. Role of callose synthases in transfer cell wall development of Arabidopsis tocopherol deficient mutants. Front. Plant Sci. 2014, 5, 46. [CrossRef] [PubMed]

71. Stewart, J.J.; Polutchko, S.K.; Adams, W.W., III; Cohu, C.M.; Wenzl, C.A.; Demmig-Adams, B. Light, temperature, and tocopherol status influence foliar vascular anatomy and leaf function in Arabidopsis thaliana. Physiol. Plant. 2017, 160, 98-110. [CrossRef] [PubMed]

72. Stewart, J.J.; Adams, W.W., III; Cohu, C.M.; Demmig-Adams, B. Tocopherols modulate leaf vein arrangement and composition without impacting photosynthesis. Photosynthetica 2018. [CrossRef]

73. Hacke, U.G.; Sperry, J.S. Functional and ecological xylem anatomy. Perspect. Plant Ecol. Evol. Syst. 2001, 4, 97-115. [CrossRef]

74. Fichot, R.; Chamaillard, S.; Depardieu, C.; Le Thiec, D.; Cochard, H.; Barigah, T.S.; Brignolas, F. Hydraulic efficiency and coordination with xylem resistance to cavitation, leaf function, and growth performance among eight unrelated Populus deltoids $\times$ Populus nigra hybrids. J. Exp. Bot. 2011, 62, 2093-2106. [CrossRef] [PubMed]

75. Adams, W.W., III; Stewart, J.J.; Cohu, C.M.; Muller, O.; Demmig-Adams, B. Habitat temperature and precipitation of Arabidopsis thaliana ecotypes determine the response of foliar vasculature, photosynthesis, and transpiration to growth temperature. Front. Plant Sci. 2016, 7, 1026. [CrossRef] [PubMed]

76. Stewart, J.J.; Demmig-Adams, B.; Cohu, C.M.; Wenzl, C.A.; Muller, O.; Adams, W.W., III. Growth temperature impact on leaf form and function in Arabidopsis thaliana ecotypes from northern and southern Europe. Plant Cell Environ. 2016, 39, 1549-1558. [CrossRef] [PubMed]

77. Vuorinen, A.L.; Kelloniemi, J.; Valkonen, J.P.T. Why do viruses need phloem for systemic invasion of plants? Plant Sci. 2011, 181, 355-363. [CrossRef] [PubMed]

78. Hipper, C.; Brault, V.; Ziegler-Graff, V.; Revers, F. Viral and cellular factors involved in phloem transport of plant viruses. Front. Plant Sci. 2013, 4, 154. [CrossRef] [PubMed]

79. Yadeta, K.A.; Thomma, P.H.J. The xylem as battleground for plant hosts and vascular wilt pathogens. Front. Plant Sci. 2013, 4, 97. [CrossRef] [PubMed]

80. Li, X.P.; Gilmore, A.M.; Caffarri, S.; Bassi, R.; Golan, T.; Kramer, D.; Niyogi, K.K. Regulation of photosynthetic light harvesting involves intrathylakoid lumen $\mathrm{pH}$ sensing by the PsbS protein. J. Biol. Chem. 2004, 279, 22866-22874. [CrossRef] [PubMed]

81. Johnson, M.P.; Ruban, A.V. Restoration of rapidly reversible photoprotective energy dissipation in the absence of PsbS protein by enhanced $\Delta$ pH. J. Biol. Chem. 2012, 286, 19973-19981. [CrossRef] [PubMed] 
82. Strand, D.D.; Kramer, D.M. Control of non-photochemical exciton quenching by the proton circuit of photosynthesis. In Non-Photochemical Quenching and Energy Dissipation in Plants, Algae and Cyanobacteria, Advances in Photosynthesis and Respiration; Demmig-Adams, B., Garab, G., Adams, W.W., III, Govindjee, Eds.; Springer: Dordrecht, The Nertherlands, 2014; Volume 40, pp. 387-408.

83. Armbruster, U.; Leonelli, L.; Correa Galvis, V.; Strand, D.; Quinn, E.H.; Jonikas, M.C.; Niyogi, K.K. Regulation and levels of the thylakoid $\mathrm{K}^{+} / \mathrm{H}^{+}$antiporter KEA3 shape the dynamic response of photosynthesis in fluctuating light. Plant Cell Physiol. 2016, 57, 1557-1567. [CrossRef] [PubMed]

84. Krondijk, J.; Glowacka, K.; Leonelli, L.; Gabilly, S.T.; Iwai, M.; Niyogi, K.K.; Long, S.P. Improving photosynthesis by accelerating recovery from photoprotection. Science 2016, 354, 857-861. [CrossRef] [PubMed]

85. Esteban, R.; Olano, J.M.; Castresana, J.; Fernández-Marín, B.; Hernández, A.; Becerril, J.M.; García-Plazaola, J.I. Distribution and evolutionary trends of photoprotective isoprenoids (xanthophylls and tocopherols) within the plant kingdom. Physiol. Plant. 2009, 135, 379-389. [CrossRef] [PubMed]

86. Stewart, J.J.; Polutchko, S.K.; Adams, W.W., III; Demmig-Adams, B. Acclimation of Swedish and Italian ecotypes of Arabidopsis thaliana to light intensity. Photosynth. Res. 2017, 134, 215-229. [CrossRef] [PubMed]

87. Stewart, J.J.; Adams, W.W., III; Cohu, C.M.; Polutchko, S.K.; Lombardi, E.M.; Demmig-Adams, B. Differences in light-harvesting, acclimation to growth light environment, and leaf structural development between Swedish and Italian ecotypes of Arabidopsis thaliana. Planta 2015, 242, 1277-1290. [CrossRef] [PubMed]

88. Stewart, J.J.; Adams, W.W., III; Demmig-Adams, B. Photoprotection kinetics of Italian and Swedish ecotypes of Arabidopsis thaliana. Unpublished work, 2018.

89. Baker, C.R.; Stewart, J.J.; Niyogi, K.K.; Adams, W.W., III; Demmig-Adams, B. Transcriptome analysis of Italian and Swedish Arabidopsis thaliana ecotypes acclimated to contrasting environmental conditions. Manuscript in preparation.

90. Ågren, J.; Schemske, D.W. Reciprocal transplants demonstrate strong adaptive differentiation of the model organism Arabidopsis thaliana in its native range. New Phytol. 2012, 194, 1112-1122. [CrossRef] [PubMed]

91. Novillo, F.; Alonso, J.M.; Ecker, J.R.; Salinas, J. CBF2/DREB1C is a negative regulator of CBF1/DREB1B and CBF3/DREB1A expression and plays a central role in stress tolerance in Arabidopsis. Proc. Natl. Acad. Sci. USA 2004, 101, 3985-3990. [CrossRef] [PubMed]

92. Zhao, C.; Zhang, Z.; Xie, S.; Si, T.; Li, Y.; Shu, J.-K. Mutational evidence for the critical role of CBF transcription factors in cold acclimation in Arabidopsis. Plant Physiol. 2016, 171, 2744-2759. [CrossRef] [PubMed]

93. Gehan, M.A.; Park, S.; Gilmour, S.J.; An, C.; Lee, C.-M.; Thomashow, M.F. Natural variation in the C-repeat binding factor cold response pathway correlates with local adaptation of Arabidopsis ecotypes. Plant J. 2015, 84, 682-693. [CrossRef] [PubMed]

94. Monroe, J.G.; McGovern, C.; Lasky, J.R.; Grogan, K.; Beck, J.; McKay, J.K. Adaptation to warmer climates by parallel functional evolution of CBF genes in Arabidopsis thaliana. Mol. Ecol. 2016, 25, 3632-3644. [CrossRef] [PubMed]

95. Ågren, J.; Oakley, C.G.; McKay, J.K.; Lovell, J.T.; Schemske, D.W. Genetic mapping of adaptation reveals fitness tradeoffs in Arabidopsis thaliana. Proc. Natl. Acad. Sci. USA 2013, 110, 21077-21082. [CrossRef] [PubMed]

96. Cohu, C.M.; Lombardi, E.; Adams, W.W., III; Demmig-Adams, B. Increased nutritional quality of plants for long-term spaceflight missions through choice of plant variety and manipulation of growth conditions. Acta Astronaut. 2014, 94, 799-806. [CrossRef]

97. Anderson, J.M.; Chow, W.S.; Park, Y.-I. The grand design of photosynthesis: Acclimation of the photosynthetic apparatus to environmental cues. Photosynth. Res. 1995, 46, 129-139. [CrossRef] [PubMed]

98. Cohu, C.M.; Muller, O.; Adams, W.W., III; Demmig-Adams, B. Leaf anatomical and photosynthetic acclimation to cool temperature and high light in two winter versus two summer annuals. Physiol. Plant. 2014, 152, 164-173. [CrossRef] [PubMed]

99. Oakley, C.G.; Savage, L.; Lotz, S.; Larson, G.R.; Thomashow, M.F.; Kramer, D.M.; Schemske, D.W. Genetic basis of photosynthetic responses to cold in two locally adapted populations of Arabidopsis thaliana. J. Exp. Bot. 2018, 69, 699-709. [CrossRef] [PubMed]

100. Polutchko, S.K.; Stewart, J.J.; Demmig-Adams, B.; Adams, W.W., III. Evaluating the link between photosynthetic capacity and leaf vascular organization with principal component analysis. Photosynthetica 2018. [CrossRef] 
101. Krapp, A.; Hofmann, B.; Schäfer, C.; Stitt, M. Regulation of the expression of $r b c S$ and other photosynthetic genes by carbohydrates: A mechanism for the "sink regulation" of photosynthesis? Plant J. 1993, 3, 817-828. [CrossRef]

102. Krapp, A.; Stitt, M. An evaluation of direct and indirect mechanisms for the "sink-regulation" of photosynthesis in spinach: Changes in gas exchange, carbohydrates, metabolites, enzyme activities and steady-state transcript levels after cold-girdling source leaves. Planta 1995, 195, 313-323. [CrossRef]

103. Adams, W.W., III; Cohu, C.M.; Amiard, V.; Demmig-Adams, B. Associations between the acclimation of phloem-cell wall ingrowths in minor veins and maximal photosynthesis rate. Front. Plant Sci. 2014, 5, 24. [CrossRef] [PubMed]

104. Haritatos, E.; Medville, R.; Turgeon, R. Minor vein structure and sugar transport in Arabidopsis thaliana. Planta 2000, 211, 105-111. [CrossRef] [PubMed]

105. Cohu, C.M.; Muller, O.; Demmig-Adams, B.; Adams, W.W., III. Minor loading vein acclimation for three Arabidopsis thaliana ecotypes in response to growth under different temperature and light regimes. Front. Plant Sci. 2013, 4, 240. [CrossRef] [PubMed]

106. Sperry, J.S.; Venturas, M.D.; Anderegg, W.R.L.; Mencucinni, M.; Mackay, D.S.; Wang, Y.; Love, D.M. Predicting stomatal responses to the environment from the optimization of photosynthetic gain and hydraulic cost. Plant Cell Environ. 2017, 40, 816-830. [CrossRef] [PubMed]

107. Lim, C.J.; Hwang, J.E.; Chen, H.; Hong, J.K.; Yang, K.A.; Choi, M.S.; Lee, K.O.; Chung, W.S.; Lee, S.Y.; Lim, C.O. Over-expression of the Arabidopsis DRE/CRT-binding transcription factor DREB2C enhances thermotolerance. Biochem. Biophys. Res. Commun. 2007, 362, 431-436. [CrossRef] [PubMed]

108. Chen, H.; Je, J.; Song, C.; Hwang, J.E.; Lim, C.O. A proximal promoter region of Arabidopsis DREB2C confers tissue-specific expression under heat stress. J. Integr. Plant Biol. 2012, 54, 640-651. [CrossRef] [PubMed]

109. Blackman, C.J.; Brodribb, T.J.; Jordan, G.J. Leaf hydraulic vulnerability is related to conduit dimensions and drought resistance across a diverse range of woody angiosperms. New Phytol. 2010, 188, 1113-1123. [CrossRef] [PubMed]

110. Pfautch, S.; Harbusch, M.; Wesolowski, A.; Smith, R.; Macfarlane, C.; Tjoelker, M.G.; Reich, P.B.; Adams, M.A. Climate determines vascular traits in the ecologically diverse genus Eucalyptus. Ecol. Lett. 2016, 19, 240-248. [CrossRef] [PubMed]

111. Givnish, T.J. Adaptation to sun and shade: A whole-plant perspective. Aust. J. Plant Physiol. 1988, 15, 63-92. [CrossRef]

112. Goldstein, G.; Santiago, L.S.; Campanello, P.I.; Avalos, G.; Zhang, Y.-J.; Villagra, M. Facing shortage or excessive light: How tropical and subtropical trees adjust their photosynthetic behavior and life history traits to a dynamic forest environment. In Tropical Tree Physiology: Adaptations and Responses in a Changing Environment, Tree Physiology; Goldstein, G., Santiago, L.S., Eds.; Springer: Dordrecht, The Netherlands, 2016; Volume 6, pp. 319-336.

113. Evans, J.R.; Poorter, H. Photosynthetic acclimation of plants to growth irradiance: The relative importance of specific leaf area and nitrogen partitioning in maximizing carbon gain. Plant Cell Environ. 2001, 24, 755-767. [CrossRef]

114. Niinemets, U. The controversy over traits conferring shade-tolerance in trees: Ontogenetic changes revisited. J. Ecol. 2006, 94, 464-470. [CrossRef]

115. Killi, D.; Bussotti, F.; Raschi, A.; Haworth, M. Adaptation to high temperature mitigates the impact of water deficit during combined heat and drought stress in C3 sunflower and C4 maize varieties with contrasting drought tolerance. Physiol. Plant. 2017, 159, 130-147. [CrossRef] [PubMed]

116. Scarpella, E.; Barkoulas, M.; Tsiantis, M. Control of leaf and vein development by auxin. Cold Spring Harb. Perspect. Biol. 2010, 2, a001511. [CrossRef] [PubMed]

117. Verna, C.; Sawchuk, M.G.; Linh, N.M.; Scarpella, E. Control of vein network topology by auxin transport. BMC Biol. 2015, 13, 94. [CrossRef] [PubMed]

118. McAdam, S.A.M.; Eléouët, M.P.; Best, M.; Brodribb, T.J.; Murphy, M.C.; Cook, S.D.; Dalmais, M.; Dimitriou, T.; Gélinas-Marion, A.; Gill, W.M.; et al. Linking auxin with photosynthetic rate via leaf venation. Plant Physiol. 2017, 175, 351-360. [CrossRef] [PubMed]

119. Hu, H.; Dai, M.; Yao, J.; Xiao, B.; Li, X.; Zhang, Q.; Xiong, L. Overexpressing a NAM, ATAF, and CUC (NAC) transcription factor enhances drought resistance and salt tolerance in rice. Proc. Natl. Acad. Sci. USA 2006, 103, 12987-12992. [CrossRef] [PubMed] 
120. Yu, H.; Chen, X.; Hong, Y.-Y.; Wang, Y.; Xu, P.; Ke, S.-D.; Liu, H.-Y.; Shu, J.-K.; Oliver, D.J.; Xiang, C.-B. Activated expression of an Arabidopsis HD-START protein confers drought tolerance with improved root system and reduced stomatal density. Plant Cell 2008, 20, 1134-1151. [CrossRef] [PubMed]

121. Nelson, D.E.; Repetti, P.P.; Adams, T.R.; Creelman, R.A.; Wu, J.; Warner, D.C.; Anstrom, D.C.; Bensen, R.J.; Castiglioni, P.P.; Donnarummo, M.G.; et al. Plant nuclear factor Y (NF-Y) B subunits confer drought tolerance and lead to improved corn yields on water-limited acres. Proc. Natl. Acad. Sci. USA 2007, 104, 16450-16455. [CrossRef] [PubMed]

122. Karaba, A.; Dixit, S.; Greco, R.; Aharoni, A.; Trijatmiko, K.R.; Marsch-Martinez, N.; Krishnan, A.; Nataraja, K.N.; Udayakumar, M.; Pereira, A. Improvement of water use efficiency in rice by expression of HARDY, an Arabidopsis drought and salt tolerance gene. Proc. Natl. Acad. Sci. USA 2007, 104, 15270-15275. [CrossRef] [PubMed]

123. Bartels, D.; Phillips, J. Drought stress tolerance. In Genetic Modification of Plants, Biotechnology in Agriculture and Forestry; Kempken, F., Jung, C., Eds.; Springer: Berlin/Heidelberg, Germany, 2010; Volume 64, pp. 139-157.

(C) 2018 by the authors. Licensee MDPI, Basel, Switzerland. This article is an open access article distributed under the terms and conditions of the Creative Commons Attribution (CC BY) license (http://creativecommons.org/licenses/by/4.0/). 